\title{
Prospective teachers' understanding of environmental ethics approach: A qualitative study
}

\author{
Senar Temel ${ }^{1, *}$ \\ ${ }^{1}$ Hacettepe University, Department of Mathematics and Science Education, 06800, Beytepe, Ankara, \\ Turkey
}

\begin{abstract}
This study aims to determine prospective teachers' understanding of environmental ethics approach. The study employed qualitative research method. 20 prospective teachers were included in the research. The participants were chosen in purposeful sampling method. The research data were collected through a test of two open-ended questions developed by the researcher. The prospective teachers were asked questions on what environmental ethics approach meant, what the importance of environmental ethics in a globalizing world is and they were required to answer the questions in writing. The written answers were analyzed via content analysis. The findings obtained through content analysis were divided into categories related to the environmental ethics approach and then the themes were defined. After the analysis of the themes and categories, prospective teachers' understanding about the environmental ethics approach was revealed and then the findings were discussed in details.

Keywords: Content analysis; environmental ethics; prospective teachers; understanding
\end{abstract}

\section{Introduction}

Environmental ethics approach, which examines the moral dimension of human beings' relations with their surroundings [1] leads us to inquiry our behaviors against the environment. According to Miloradova and Ishkov [2], it is a social and humanitarian value. Environmental ethics approach aims to provide ethical justification and moral motivation for the cause of global environmental protection [3]. However, this approach has been accepted as a sub-branch of philosophy since the 1970s [4]. Not giving importance to environmental ethics is one of the reasons for environmental problems. In addition to this, the adoption of anthropocentric ethical approach, especially, leads to global environmental problems. In the anthropocentric ethical approach only human beings have moral value [5]. It is based on the view of human nature as the master of nature [6]. At this point, the importance of peoples' awareness in their relations with the environment and which environmental ethics approach is adopted is increasing. An external intervention by

\footnotetext{
*Corresponding author: senarhacettepe@gmail.com
} 
the human to the natural environment leads to the deterioration of the ecological balance and environmental problems [7]. Gamayunova and Vatin [8] emphasized moral human problems, which are both the social relationships of people, and the responsibility for the welfare of future people, animals and other life forms. In terms of ethics, behaviors that do not take into account the quality of life and the standards of the next generations, and that will destroy the resources that will increase their well-being, are not considered as ethical behavior even if they appear to be beneficial for the present generation [9]. So which environmental ethics approach that tries to determine which behaviors towards the environment correct are, are perceived truly by prospective teachers who will raise the future generations is so important in terms of transferring the correct approach to their students. Thus, this study intends to analyze prospective teachers' understanding of environmental ethics approach.

\subsection{The aim of the study}

This study aims to determine prospective teachers' understanding of environmental ethics approach.

\section{Method}

The study employed qualitative research method. It is useful for describing or answering questions about particular, localized occurrences of contexts and the perspectives of a participant group towards events, beliefs of practices [10].

\subsection{Study group}

The study group was composed of 20 prospective teachers. All of the participants took a course in Environmental Protection in 2018-2019 academic year. The participants were chosen through purposeful sampling method. Purposeful sampling is a method enabling researchers to examine the situations having rich information in depth and thus to illuminate better the questions that a study focuses on [11]. All the participants were included in the study on the basis of volunteering. Prior to the study, they were informed of the content, evaluation of the data and confidentiality of their names.

\subsection{Data collection tool}

The research data were collected through a test including two open-ended questions developed by the researcher. The test questions were prepared by reviewing the studies available in the literature. The data were collected in the spring semester of 2018-2019 academic year. The participants were allowed 20 minutes to respond to the questions. They were asked questions about what environmental ethics approach meant, what the importance of environmental ethics in a globalizing world is; and they were required to answer the questions in writing.

\subsection{Analyses of the data}

The written answers given by the prospective teachers to the open-ended questions were analyzed via content analysis. Content analysis was preferred to reach the concepts and relations, which would be able to explain the data collected [12]. Firstly, codes were created. Then findings were analyzed in categories and then themes were distinguished. 
Expert opinion was consulted in analyzing the qualitative data and thus efforts were made to raise internal validity. Similarities and differences in coding between the researcher and expert were compared and interrater reliability was found to be $89 \% .70 \%$ reliability should be attained at the minimum in qualitative studies $[13,12]$.

\section{Findings}

The findings obtained through content analysis are shown in Table 1.

Table 1. Content analysis findings related to environmental ethics approach

\begin{tabular}{|c|c|c|c|}
\hline Theme & Category & Code & Frequency \\
\hline \multirow{28}{*}{ 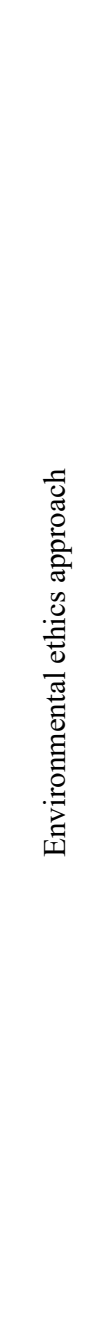 } & \multirow{12}{*}{ 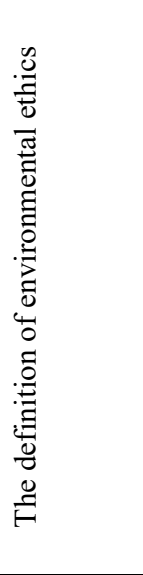 } & $\begin{array}{l}\text { Examination of the moral relations between human and } \\
\text { nature }\end{array}$ & 12 \\
\hline & & Securing sustainable environment & 9 \\
\hline & & Leaving a liveable environment to next generations & 8 \\
\hline & & Respecting the environment & 6 \\
\hline & & Raising environmental awareness to people & 6 \\
\hline & & Not considering the environment as an exploited value & 6 \\
\hline & & Respecting all organisms' right to live & 5 \\
\hline & & Gaining environmental moral & 4 \\
\hline & & $\begin{array}{l}\text { People's avoidance of living selfishly without thinking } \\
\text { of nature }\end{array}$ & 2 \\
\hline & & Humans' considering themselves as a part of nature & 2 \\
\hline & & $\begin{array}{l}\text { The form of human-nature or human-living things } \\
\text { relations }\end{array}$ & 1 \\
\hline & & Avoiding behaviours which disturb ecological balance & 1 \\
\hline & \multirow{16}{*}{ 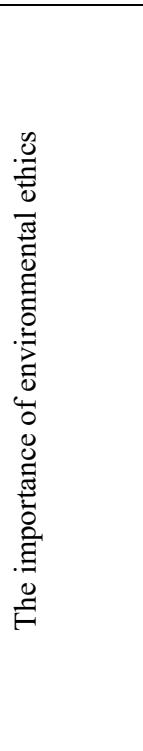 } & $\begin{array}{l}\text { Not being able to meet the needs of next generations } \\
\text { from the environment }\end{array}$ & 11 \\
\hline & & Prevent environmental damage & 7 \\
\hline & & Pointing good behaviours for the environment & 7 \\
\hline & & Avoiding bad behaviours for the environment & 7 \\
\hline & & Being sensitive to the environment & 6 \\
\hline & & $\begin{array}{l}\text { Providing individuals with right of habitable } \\
\text { environment }\end{array}$ & 5 \\
\hline & & Respecting nature's capacity to renew itself & 4 \\
\hline & & Guiding others in securing the sustainable environment & 4 \\
\hline & & $\begin{array}{l}\text { Realizing that selfish behaviours have bad consequences } \\
\text { in nature }\end{array}$ & 4 \\
\hline & & Securing harmony with nature & 3 \\
\hline & & $\begin{array}{l}\text { Being aware of the fact that the environment is entrusted } \\
\text { to us }\end{array}$ & 3 \\
\hline & & Inquiring how to behave living and non-living things & 3 \\
\hline & & Knowing our responsibilities to the environment & 2 \\
\hline & & Need for learning the language of the environment & 2 \\
\hline & & The environments' deserving being valued and respected & 2 \\
\hline & & Understanding that humans are an integral part of nature & \\
\hline
\end{tabular}

Firstly codes were formed from the prospective teachers' responses. Their responses to the questions were divided into two categories. On examining the codes in the category of the definition of environmental ethics, it was found that the majority of the prospective teachers $(60 \%)$ defined environmental ethics as examining the moral relations between human and nature. The definitions of environmental ethics offered by the prospective 
teachers also included such statements as securing the sustainable environment (45\%) and leaving liveable environment to the next generations (40\%). Respecting the environment, raising environmental awareness to people, not considering the environment as an exploited value were also the definitions made by $30 \%$ of the participants. An examination of the statements in the category of the importance of environmental ethics showed that according to most of the prospective teachers (55\%), the fact that next generations will not be able to meet their needs from the environment was the importance of environmental ethics. $35 \%$ put forward such statements as preventing harm to the environment, pointing to the behaviors good for the environment and avoiding the ones bad for the environment as the importance of environmental ethics. The other statements made by the prospective teachers in relation to the importance of environmental ethics were being sensitive to the environment $(30 \%)$, providing individuals with right of habitable environment $(25 \%)$, respecting nature's capacity to renew itself $(20 \%)$ and guiding others in securing the sustainable environment $(20 \%)$.

\section{Discussion and conclusions}

Prospective teachers' answers about the environmental ethics approach were divided into two categories labeled as the definition of environmental ethics and the importance of environmental ethics. Although the prospective teachers offered various definitions of environmental ethics- such as respecting all organisms' right to live (25\%), gaining environmental moral (20\%), people's avoidance of living selfishly without thinking of nature $(10 \%)$, humans' considering themselves as a part of nature $(10 \%)$, the form of human-nature or human-living things relations $(5 \%)$, avoiding behaviors spoiling ecological balance $(5 \%)$ - the number of those who had made the definitions were very small. The majority of them $(60 \%)$, on the other hand were found to define environmental ethics as an examination of moral relations between human and nature. It was also found that the prospective teachers made various statements also in the category of the importance of environmental ethics- securing harmony with nature, being aware of the fact that the environment is entrusted to us, inquiring how to behave living and non-living things $(15 \%)$, knowing of our responsibilities for the environment, need for learning the language of the environment, the environments' deserving being valued and respected, understanding that humans are an integral part of nature $(10 \%)$. Yet, the number of those making the statements was also small. The prospective teachers stated especially that environmental ethics was important in the fact that next generations will not be able to meet their needs from the environment (55\%) and in pointing to the behaviors good for the environment and avoiding the ones bad for the environment (35\%).

On evaluating the results in general, it was found that the prospective teachers have different ideas about the environmental ethics approach but that the number of those stating their ideas was not high. Nevertheless, it can be concluded based on the ideas they have put forward that they adopt an ecocentric environmental ethics approach. Studies are available in the literature supportive of that result. Alpak-Tunç and Yenice [14] concluded in a study analyzing prospective science teachers' ethical approaches towards the environment and their attitudes towards sustainable environment that the prospective teachers generally had ecocentric attitudes and that they had positive attitudes towards sustainable environment. Miloradova and Ishkov [2] examining university students' answers to the question of what environmental ethics was, found that that the students made such statements as necessity for protecting the environment and every individuals' responsibility for life in the world. Karakaya and Çobanoğlu [15] in a study aiming to describe university final year students' perspectives about the environment, found that the great majority of the students $(85 \%)$ had ecocentric environmental ethics approach and that they did not put humans in the center. 
Accordingly, it is important to inquire about what responsibilities prospective teachers have for the nature in raising environmental awareness in relation to their ecocentric environmental ethics approach. At this point, future studies could investigate in depth what responsibilities prospective teachers should have for the environment.

\section{References}

1. J. R. Des Jardins, Çevre etiği - Çevre felsefesine giriş. R. Keleş (Çev.) (İstanbul: İmge Kitabevi 2006)

2. N. Miloradova, A. Ishkov, Procedia Eng. 117, 246 - 251 (2015)

3. T. Yang, Towards an egalitarian global environmental ethics. Environmental ethics and international policy (UNESCO 2006)

4. F. Ağbuğa, Çevre sorunlarına etik bir yaklaşım: felsefi bir sorgulama. (Yüksek lisans tezi, Pamukkale Üniversitesi Sosyal Bilimler Enstitüsü 2016)

5. T. G. Jakobsen, J. Crit. Realism. 16, 2 (2017)

6. J. S. Armstrong, R. G. Botzler, Environmetal ethics: divergence and convergence (New York: Mc Graw-Hill 1993).

7. C. Karaca, C. U. J. Fac. Eco. and Adm. Sci, 11, 1, (2007)

8. O. Gamayunova, N. Vatin, Adv. Mater. Res. 1065-1069, 2459-2462 (2015)

9. T. Ergün, N. Çobanoğlu, A. U. J. Soc. Sci. Inst. 3, 1, (2012)

10. L. R. Gay, P. Airasian, Educational research competencies for analysis and application (6th Edition) (Ohio: Merrill an Imprint of Prentice Hall 2000)

11. M. Q. Patton, Qualitative research \& evaluation methods (3rd ed.) (Thousand Oaks, CA: Sage 2002)

12. A. Yıldırım, H. Şimşek, Sosyal bilimlerde nitel araştırma yöntemleri (8. Baskı). (Ankara: Seçkin Yayıncılık 2011)

13. B. M. Miles, A. M. Huberman, Qualitative data analysis: an extended sourcebook. (2nd edition) (Thousand Oaks, CA: Sage, England 1994).

14. G. Alpak-Tunç, N. Yenice, Int. Electron. J. Environ. Educ., 7, 1, (2017)

15. C, Karakaya, E. O. Çobanoğlu, J. Turk. Sci. Educ. 9, (2012) 